\title{
Chromovitrectomy and the Vitreoretinal Interface
}

\author{
R.G.Schumann C. Haritoglou International Chromovitrectomy Collaboration \\ Department of Ophthalmology, Ludwig Maximilian University, Munich, Germany
}

\section{Key Words}

Chromovitrectomy · Vitreoretinal interface $\cdot$ Retinal debris · Internal limiting membrane - Epiretinal membrane . Vital dye · Brilliant blue $\cdot$ Indocyanine green · Electron microscopy · Atomic force microscopy

\begin{abstract}
It still remains unclear to which extent the presence and the amount of retinal debris seen in internal limiting membrane (ILM) specimens harvested during macular surgery for macular holes or epiretinal membranes are related to the procedure of ILM peeling itself or to modifications of the surgical technique, such as application of vital dyes for visualization of the ILM, or to pathological conditions with epiretinal membrane formation at the vitreoretinal interface. The presence of cellular fragments on the retinal side of the removed ILM appears to be of multifactorial origin, and additional causes besides dye application need to be considered. However, morphological studies with evaluation of vital dyes are still of relevance and provide additional insights into the ultrastructure of the vitreoretinal interface and its interaction with adjuvants used during macular surgery. Chromovitrectomy is an emerging field in vitreoretinal surgery. It is of importance to better understand the tissue-dye interactions, which not only alter the mechanical properties of the tissue being stained, but may also have an impact on the functional result postoperatively.

(c) 2013 S. Karger AG, Basel
\end{abstract}

(c) 2013 S. Karger AG, Base

0030-3755/13/2306-0003\$38.00/0

\section{Introduction}

The removal of the internal limiting membrane (ILM) has become a widely accepted procedure during vitreoretinal surgery for the treatment of traction maculopathies such as macular holes or epimacular membranes [1,2]. Given the close anatomical situation, removal of the ILM during macular surgery bears the potential of damaging inner retinal layers, thereby possibly inducing retinal dysfunction. The ILM is the basal lamina of Müller glial cells being directly adjacent to Müller cell footplates (fig. 1). To date, it is generally assumed that the ILM is not replaced or regenerated after its removal during macular surgery.

Vital dyes such as brilliant blue G (BBG) and indocyanine green (ICG) have been introduced to facilitate this challenging surgical maneuver and to reduce excessive manipulation on the innermost retinal layers, thereby minimizing the risk of functional postoperative deficits that result from mechanical trauma to the tissue [3]. However, it became apparent that especially the use of ICG may be associated with postoperative complications such as visual field defects $[4,5]$ or morphological alterations of the macular area [6-9]. Although the underlying pathomechanisms are still not completely understood, there is some evidence that the photosensitizing properties of ICG and its degradation products are one relevant aspect in this context [10-12]. It has furthermore been discussed in the literature whether vital dyes used during

\section{KARGER}

E-Mail karger@karger.com

www.karger.com/oph
Ricarda G. Schumann, MD

Department of Ophthalmology

Vitreoretinal and Pathology Unit, Ludwig Maximilian University

Mathildenstrasse 6, DE-80336 Munich (Germany)

E-Mail ricarda.schumann@med.uni-muenchen.de 
Fig. 1. Morphology of the vitreoretinal interface of the human retina. a Transmission electron micrograph demonstrating the ILM (asterisk) which is characterized by an undulated retinal side and a smooth vitreal side. The typical undulations on the retinal side are directly adjacent to the Müller cell end feet (MCE) within the retinal nerve fiber layer. This topographic feature allows for a clear differentiation between epiretinal cell proliferation and retinal cell debris. b Scanning electron micrograph showing cellular processes of an epiretinal membrane on the vitreal side and button-like undulations of the retinal side of a surgically removed and folded ILM specimen. a Original magnification $\times 9,500$; scale bar $=1.1 \mu \mathrm{m}$. b Original magnification $\times 1,800$; scale bar $=5.6 \mu \mathrm{m}$.

Fig. 2. Ultrastructure of surgically removed ILM specimens. a Transmission electron micrograph presenting a blank ILM neither with epiretinal cell proliferation nor with cell debris on the retinal side of the ILM. b Transmission electron micrograph demonstrating entire cell bodies on the retinal side of the ILM that interdigitate with the typical undulations of the ILM. a Original magnification $\times 1,800$; scale bar $=5.6$ $\mu \mathrm{m}$. b Original magnification $\times 4,800$; scale bar $=2.0 \mu \mathrm{m}$.
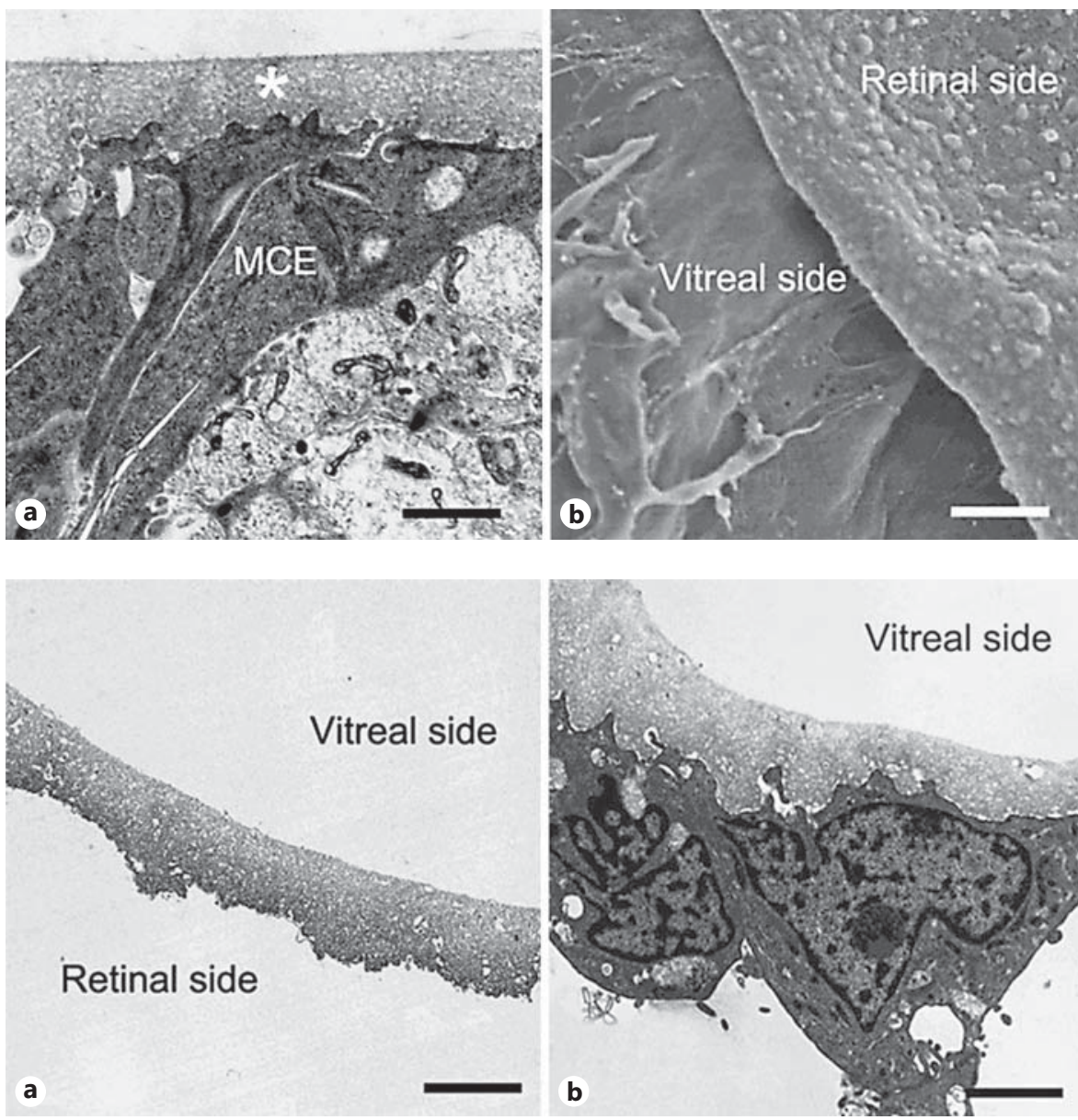

surgery interfere with the architecture of the vitreoretinal interface by altering the cleavage plane from the retinal surface of the ILM to the innermost layers of the retina. This hypothesis was based on the observation of retinal debris adherent to the retinal surface of the ILM removed after staining of the macular area during vitreoretinal interventions and on differences of the amount of such debris depending on the dye used compared to conventional ILM peeling without staining [13-17].

However, changes in retinal architecture remain incompletely understood. There are ongoing investigations to elucidate the question to what extent if at all morphological changes correlate with the intravitreal application of vital dyes or are the result of the removal of the ILM itself. Furthermore, it is still a matter of controversy whether structural alterations of retinal layers after dyeassisted ILM peeling impair retinal function permanently or rather induce transient visual disturbances.

\section{Do Vital Dyes Alter the Cleavage Plane during Vitreoretinal Procedures?}

Although ILM peeling is widely considered an essentially safe surgical technique, removal of the ILM may sometimes lead to the presence of cell fragments or entire cell bodies on the retinal side of the peeled ILM (fig. 2).

Light- and electron-microscopic studies as well as immunohistochemical studies demonstrated retinal cell debris on the ILM which was assigned to glial cells and neuronal cell debris, in particular Müller cell end feet and cell fragments of the retinal nerve fiber layer $[8,9$, 13-18]. Even without the use of vital dyes to assist macular surgery, it has been suggested that the presence of cellular debris adherent to the retinal side of the ILM is somehow inevitable as the ILM cannot be removed from the retinal surface without disrupting the underlying Müller cells, as the ILM represents their basal lamina and 
Fig. 3. Quantification scale of retinal cell fragments on the ILM (asterisk) characterized by transmission electron microscopy. a Small $(<1 \mu \mathrm{m}$ in diameter $)$ and solitarily distributed round cell fragments (arrows). b Medium-sized (1-2 $\mu \mathrm{m}$ in diameter) round cell fragments (arrows). c Large ( $>2$ $\mu \mathrm{m}$ in diameter) cell fragments (arrows) derived from nerve fiber bundles and retinal cells, such as a cell nucleus (arrowhead). d Entire cell body with cellular nucleus (arrows) and cellular organelles such as mitochondria, endoplasmic reticulum and Golgi complexes (arrowheads). a, d Original magnification $\times 9,500$; scale bar $=1.0 \mu \mathrm{m}$. b, c Original magnification $\times 4,800$; scale bar $=2.0 \mu \mathrm{m}$.
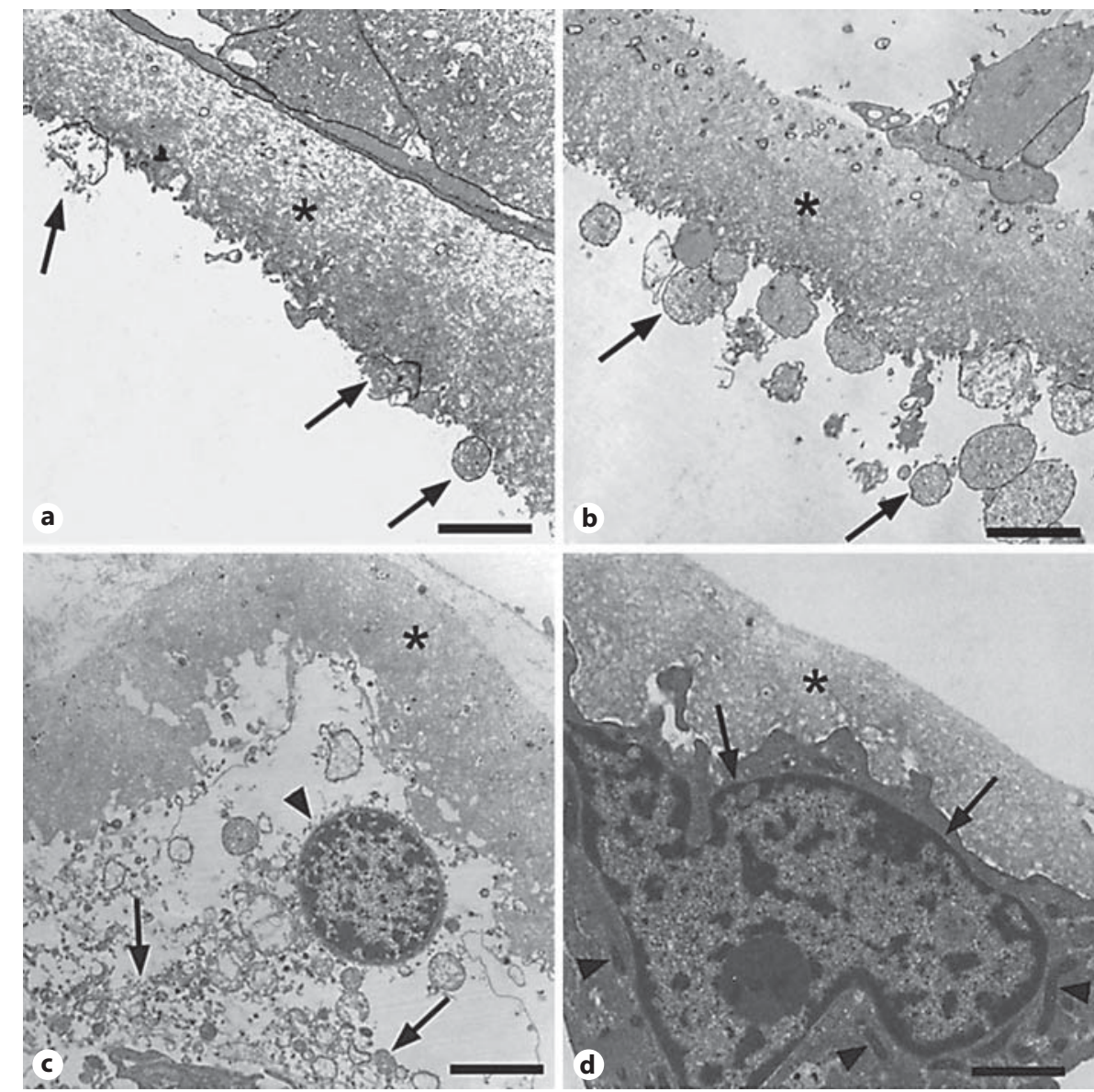

is therefore intimately associated with their plasma membrane [19].

However, in general there is difficulty to define the amount of retinal cell debris on the ILM, especially since cross-section preparation techniques of ILM specimens are examined in most studies. Cross-sections usually cover only a limited part of the whole specimen. Consequently, it is mandatory to examine a large number of sections. In that context, a grading system was suggested to analyze retinal cell debris based on the size and structural appearances of retinal cell fragments [13, 20] (fig. 3).

In fact, it appears that the presence and size of cellular fragments may be related to known topographical variations of the ILM. While the vitreal side of the ILM appears smooth throughout the retinal surface, there are distinct morphological variations of the retinal side when comparing the ILM at the posterior pole to the ILM in the periphery: at the posterior pole, the retinal surface is irregular with undulations filling the spaces between adjacent cellular components (such as Müller cell end feet)

Chromovitrectomy and the Vitreoretinal Interface and the ILM. These undulations increase not only the surface in contact with the underlying retinal cellular structures, but also the adhesion of the ILM in the area of the posterior pole. Therefore, it seems plausible that discrete disruption of Müller cell footplates in terms of a mechanical trauma during ILM peeling predominantly occurs in these areas, as described in the literature [17]. The lamellar and round structures observed in some sections were identified as the inner portion of Müller cells. Small round and lamellar structures were often seen in contact with such undulations of the ILM and most probably originate from Müller cell plasma membranes and fragments of Müller cell end feet having remained adherent to the posterior (retinal) portion of the ILM during ILM stripping [13-15, 17].

In contrast, a greater amount of cellular fragments in all specimens investigated were noted after ICG staining. Compared to unstained ILM specimens, masses of cellular debris were found throughout the retinal surface of the ILM, both in areas with and without irregularities of the 
retinal surface of the ILM $[8,9]$. Moreover, after administration of trypan blue (TB), BBG, bromophenol blue and Chicago blue during ILM peeling, rather small and rare cell fragments on the retinal side of the ILM were demonstrated showing significantly fewer cell fragments on the retinal side of the ILM than after ICG-assisted ILM peeling [13].

Furthermore, a recent histological study focused on detecting large cell fragments of more than $2 \mu \mathrm{m}$ and entire cell bodies on the retinal side of the ILM by light microscopy and subsequent further analysis by transmission electron microscopy [20]. When screening serial sections, large cell debris on the retinal side of the ILM was found in only $19 \%$ of all 120 specimens investigated. This cohort of specimens allowed comparison of cellular elements on the retinal side of the ILM in different traction maculopathies, in the presence and absence of epiretinal cell proliferation, and in cases of ILM peeling with and without dye assistance using BBG or TB. Removal of large cellular structures during ILM peeling was reported to be most importantly associated with epiretinal cell proliferation. The presence of cell fragments of more than $2 \mu \mathrm{m}$ in diameter and the presence of entire cell bodies on the retinal side of the ILM seemed unrelated to the use of BBG and TB.

In addition, since epiretinal membrane formation might also be associated with glial cell migration and proliferation beneath the ILM in different traction maculopathies by responding to tissue stretch [21, 22], large cell fragments on the retinal side of the ILM may originate from other cell structures than small cell fragments. Thus, it might be hypothesized that large retinal cell fragments of more than $2 \mu \mathrm{m}$ and entire cell bodies which are occasionally removed during ILM peeling may represent migrating and proliferating glial cells or microglial cells.

\section{The Role of Epiretinal Cell Proliferation}

One may hypothesize that the presence of epimacular membranes might contribute to the unintended removal of retinal cell fragments during ILM peeling. A multilayered cell composition such as an epiretinal membrane represents a more rigid structure compared to the bare ILM. Therefore, the presence of retinal debris on the removed ILM could result from a mechanical trauma to underlying structures by pulling off the rigid membrane. It was hypothesized that epiretinal membrane formation may alter cell-cell or cell-matrix adhesion interactions on both sides of the ILM [20].
Furthermore, glial cell proliferation is generally supposed to be associated with epimacular membranes on the vitreal side of the ILM, but occasionally it was also shown along the retinal surface of the ILM [23]. As mentioned earlier, the presence of cellular debris may be the result of this specific growth pattern. This hypothesis is in accordance with a recent immunohistochemical study of retinal cell debris on the ILM that demonstrated anti-glial fibrillary acidic protein-positive retinal cell fragments in correlation with the presence of epiretinal membranes [18]. Using light microscopy, this study did not confirm any influence of TB, ICG, or BBG on the removal of large retinal cell fragments and entire cell bodies during ILM peeling. However, significantly fewer retinal cell fragments on the ILM were seen following macular hole surgery, where the formation of epiretinal cell proliferation is less pronounced, compared to ILM specimens from epimacular membrane surgery. The authors suggested that the plane of dissection during ILM peeling may be altered by the formation of epiretinal membranes and/or the pathology inducing the development of an epiretinal membrane such as the modulation of glial fibrillary acidic protein within Müller cells.

In addition, it was suggested that there is continuity between components of epimacular membranes and the retinal cell layers through pores of the ILM, which may increase the adhesion forces between these cells and the ILM. In this context, Wolter [24] reported on pores in the ILM of the human retina. Other investigators also demonstrated glial cells crossing the ILM using transmission electron microscopy [25-27]. More recently, Gandorfer et al. [28] systematically screened 112 ILM specimens from patients with idiopathic macular holes by using the flat-mount preparation technique to assess surgical ILM specimens en face. However, they only found a few pores concluding that retinal glial cells may use other pathways as well to migrate onto the vitreal side of the ILM in epiretinal proliferation.

\section{Vital Dyes Increase the Stiffness of the ILM}

The ILM represents a delicate tissue of variable thickness with $0.5-3.2 \mu \mathrm{m}$ at the posterior pole and $0.01-0.10$ $\mu \mathrm{m}$ at the fovea and the disk [29]. With regard to its thickness, the ILM is stiff with a mechanical strength in the millipascal range, very similar to articular cartilage and about 1,000-fold stronger than cell layers [30, 31]. The retinal side is approximately 5 -fold stiffer than the vitreal side [32], which explains the typical rolling of the tissue DOI: $10.1159 / 000353864$
Schumann/Haritoglou 
when being peeled off during surgery (fig. 4). The high mechanical strength of the natural ILM explains why it can be grasped with a forceps and be peeled off mechanically from the underlying nerve fiber layer.

It is a common intraoperative observation that the stained ILM, either using ICG or BBG, can be removed much more easily and in larger fragments compared to unstained tissue. This observation was interpreted as an alteration of the cleavage plane to innermost retinal layers, supported by the presence of retinal cellular components as discussed above. However, this phenomenon is very likely explainable by specific tissue-dye interactions: For ICG, Wollensak et al. [33] and Wollensak [34] reported an increased stiffness of the ICG-stained ILM following 3-min illumination of the stained postmortem porcine retina, showing a significant increase in ultimate force by $45 \%$ and a decrease in ultimate elongation by $24 \%$. Interestingly, no such effect was seen without subsequent illumination suggesting a light-dependent process. They therefore concluded that the stiffening effect of ICG combined with light is related to a photosensitizing effect of ICG by the formation of a triplet state of the ICG molecule and reactive oxygen species (type I reaction of photooxidation) [34, 35].

Using atomic force microscopy, our group was able to show that the use of BBG and ICG significantly increases the stiffness of the ILM [data submitted]. Interestingly, additional illumination did not provide a significant additive effect. With this background it seems very likely that the presence of retinal debris at the retinal side of the ILM is more or less related to the increased stiffness of the tissue that is peeled off during surgery, and is not related to the specific dye used for peeling. Therefore, toxic effects of a dye such as ICG are more likely related to its degradation products and cannot be correlated with peculiar morphological findings alone.

\section{Retinal Function and Chromovitrectomy}

Nevertheless, electron-microscopic analysis was the first investigation showing potential retinal damage after ICG staining and represented the first attempt to explain poor functional outcome as seen in some patients after chromovitrectomy [4-9]. Since then, the question of dyerelated toxicity was critically reassessed and revisited in several experimental and clinical trials [36-41]. At present, numerous dyes are being investigated in cell culture models and animal studies to carefully assess the issue of toxicity prior to the use in humans $[13,16,42-50]$.

Chromovitrectomy and the Vitreoretinal Interface

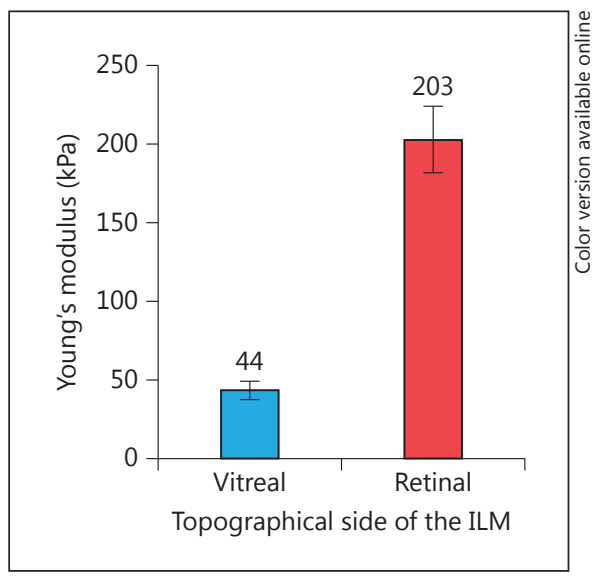

Fig. 4. By atomic force microscopy, stiffness measurements (mean of force map results, ILM-operative) of surgically excised ILM specimens demonstrate that the retinal side of the ILM is approximately 5 -fold stiffer than the vitreal side.

However, it is noteworthy that the presence of retinal cell fragments could not be directly correlated with adverse functional outcome as determined by visual acuity and visual field testing or anatomical success as determined by macular hole closure, since the morphological observations were made in all specimens obtained during surgery, but were (only) associated with visual field defects in approximately 50\% [51]. This observation underlines that morphological examinations alone and the hypothesis of a dye-related alteration of the surgical cleavage plane are not sufficient to explain the pathomechanism of ICG-related toxicity.

Until the introduction of ICG for ILM peeling and the reports on potential ICG-related toxic effects, only single reports related ILM peeling to impaired functional outcome [52]. However, subtle functional and morphological alterations were infrequently observed following macular surgery with ILM peeling, including changes of the focal macular electroretinogram (ERG) [53], dissociated optic nerve fiber layer (DONFL) appearance [54-56], paracentral scotomata or visual field defects $[57,58]$.

Recent investigations supported the hypothesis that ILM peeling itself may change retinal morphology and impair retinal function. A clinicopathological study correlated retinal cell fragments of large size, namely retinal cell fragments of more than $2 \mu \mathrm{m}$ in diameter, on the removed ILM with changes in macular dysfunction on the multifocal ERG [59]. This study suggested that large cell fragments on the retinal side of the ILM are related to Müller cell damage with transient alterations of retinal

Ophthalmologica 2013;230(suppl 2):3-10 DOI: $10.1159 / 000353864$ 
function after triamcinolone-assisted ILM peeling. In accordance with these findings, Terasaki et al. [53] demonstrated a limited and delayed response of the focal macular ERG after ILM peeling suggesting that ILM removal during macular hole surgery could damage retinal Müller cells. Similarly, Tari et al. [60] proposed that dysfunction of retinal Müller cells might play an important role in modulating synaptic transmission in the neuronal retinal composition based on their findings of decreased responses in multifocal ERG after ILM peeling. Furthermore, damage to retinal Müller cells or Müller cell end feet may be related to DONFL appearance of the fundus after uneventful ILM peeling [54-56]. However, Mitamura and Ohtsuka [56] did not find any significant difference between the zone of DONFL appearance and normal retina concerning the microperimetry threshold values, suggesting there was no loss of optic nerve fibers.

With regard to dye assistance in ILM removal, Christensen et al. [61] reported on the same incidence of DONFL appearance in ICG-peeled and TB-peeled eyes, suggesting that the surgical procedure itself was responsible for this clinical feature after ILM removal. Nevertheless, inner retinal defects may frequently occur after ILM peeling as described by Alkabes et al. [62] using en face spectral domain optical coherence tomography after macular hole surgery with dye assistance. They reported on postoperative inner retinal defects, named concentric macular dark spots, in the same direction as the optic nerve fibers. These defects were not progressive and were most probably related to the procedure of ILM peeling itself rather than to the administration of vital dyes.

\section{Conclusion}

It still remains unclear to which extent the presence and the amount of retinal debris seen in ILM specimens harvested during macular surgery for macular holes or epiretinal membranes are related to the procedure of ILM peeling itself or to modifications of the surgical technique, such as application of vital dyes for visualization of the ILM, or to pathological conditions with epiretinal membrane formation at the vitreoretinal interface. The presence of cellular fragments on the retinal side of the removed ILM appears to be of multifactorial origin, and additional causes besides dye application need to be considered. However, morphological studies with evaluation of vital dyes are still of relevance and provide additional insights into the ultrastructure of the vitreoretinal interface and its interaction with adjuvants used during macular surgery. Chromovitrectomy is an emerging field in vitreoretinal surgery. It is of importance to better understand the tissue-dye interactions, which not only alter the mechanical properties of the tissue being stained, but may also have an impact on the functional result postoperatively.

\section{Disclosure Statement}

The authors have no proprietary interest in any aspect of this study. Conflict of interest: none. Source of funding: none.

\section{References}

1 Brooks HL Jr: Macular hole surgery with and without internal limiting membrane peeling. Ophthalmology 2000;107:1939-1948.

-2 Park DW, Dugel PU, Garda J, Sipperley JO, Thach A, Sneed SR, Blaisdell J: Macular pucker removal with and without internal limiting membrane peeling: pilot study. Ophthalmology 2003;110:62-64.

3 Kadonosono K, Itoh N, Uchio E, Nakamura S, Ohno S: Staining of the internal limiting membrane in macular hole surgery. Arch Ophthalmol 2000;118:1116-1118.

4 Uemura A, Kanda S, Sakamoto Y, Kita H: Visual field defects after uneventful vitrectomy for epiretinal membrane with indocyanine green-assisted internal limiting membrane peeling. Am J Ophthalmol 2003;136:252-257.
5 Tsuiki E, Fujikawa A, Miyamura N, Yamada K, Mishima K, Kitaoka T: Visual field defects after macular hole surgery with indocyanine green-assisted internal limiting membrane peeling. Am J Ophthalmol 2007; 143:704-705.

-6 Baba T, Hagiwara A, Sato E, Arai M, Oshitari T, Yamamoto S: Comparison of vitrectomy with brilliant blue $\mathrm{G}$ or indocyanine green on retinal microstructure and function of eyes with macular hole. Ophthalmology 2012;119: 2609-2615.

7 Engelbrecht NE, Freeman J, Sternberg P Jr, Aaberg TM Jr, Aaberg TM Sr, Martin DF, Sippy BD: Retinal pigment epithelial changes after macular hole surgery with indocyanine green-assisted internal limiting membrane peeling. Am J Ophthalmol 2002;133:89-94.
8 Haritoglou C, Gandorfer A, Gass CA, Schaumberger M, Ulbig MW, Kampik A: Indocyanine green-assisted peeling of the internal limiting membrane in macular hole surgery affects visual outcome: a clinicopathologic correlation. Am J Ophthalmol 2002;134: 836-841.

-9 Gandorfer A, Haritoglou C, Gass CA, Ulbig MW, Kampik A: Indocyanine green-assisted peeling of the internal limiting membrane may cause retinal damage. Am J Ophthalmol 2001;132:431-433.

10 Yam HF, Kwok AK, Chan KP, Lai TY, Chu KY, Lam DS, Pang CP: Effect of indocyanine green and illumination on gene expression in human pigment epithelial cells. Invest Ophthalmol Vis Sci 2003;44:370-377. 
11 Hillenkamp J, Dydykina S, Klettner A, 23 Haritoglou C, Schumann RG, Kampik A, Treumer F, Vasold R, Bäumler W, Roider J: Safety testing of indocyanine green with different surgical light sources and the protective effect of optical filters. Retina 2010;30:16851691.

12 Sato T, Ito M, Ishida M, Karasawa Y: Phototoxicity of indocyanine green under continuous fluorescent lamp illumination and its prevention by blocking red light on cultured Müller cells. Invest Ophthalmol Vis Sci 2010; 51:4337-4345.

13 Schumann RG, Gandorfer A, Priglinger SG, Kampik A, Haritoglou C: Vital dyes for macular surgery: a comparative electron microscopy study of the internal limiting membrane after macular surgery. Retina 2009;29:669676.

14 Eckardt C, Eckardt U, Groos S, Luciano L, Reale E: Removal of the internal limiting membrane in macular holes. Clinical and morphological findings. Ophthalmologe 1997;94:545-551.

-15 Schumann RG, Schaumberger MM, Rohleder M, Haritoglou C, Kampik A, Gandorfer A: Ultrastructure of the vitreomacular interface in full-thickness idiopathic macular holes: a consecutive analysis of 100 cases. Am J Ophthalmol 2006;141:1112-1119.

16 Remy M, Thaler S, Schumann RG, May CA, Fiedorowicz M, Schuettauf F, Grüterich M, Priglinger SG, Nentwich MM, Kampik A, Haritoglou C: An in-vivo evaluation of brilliant blue $\mathrm{G}$ in animals and humans. Br J Ophthalmol 2008;92:1142-1147.

$\checkmark 17$ Haritoglou C, Schumann R, Reiniger I, Rohleder M, Priglinger SG, Kampik A, Gandorfer A: Evaluation of the ILM after conventional peeling during macular hole surgery. Retina 2006;26:21-24.

-18 Kenawy N, Wong D, Stappler T, Romano MR, Das RA, Hebbar G, Prime W, Heimann H, Gibran SK, Sheridan CM, Cheung YH, Hiscott PS: Does the presence of an epiretinal membrane alter the cleavage plane during internal limiting membrane peeling? Ophthalmology 2010;117:320-323.

19 Eagle RC: Wills Eye Hospital; in Rapuano CJ (ed): Year Book of Ophthalmology. St Louis, Mosby, 2003, pp 276-278.

20 Schumann RG, Yang Y, Haritoglou C, Schaumberger MM, Eibl KH, Kampik A, Gandorfer A: Histopathology of internal limiting membrane peeling in traction induced maculopathies. J Clin Exp Ophthalmol 2012; 3:4-10.

21 Bringmann A, Wiedemann P: Involvement of Müller glial cells in epiretinal membrane formation. Graefes Arch Clin Exp Ophthalmol 2009;247:865-883.

-22 Lindqvist N, Liu Q, Zajadacz J, Franze K, Reichenbach A: Retinal glial (Müller) cells: sensing and responding to tissue stretch. Invest Ophthalmol Vis Sci 2010;51:1683-1690. Gandorfer A: Glial cell proliferation under the internal limiting membrane in a patient with cellophane maculopathy. Arch Ophthalmol 2007;125:1301-1302.

24 Wolter RJ: Pores in the inner limiting membrane of the human retina. Acta Ophthalmol 1964;42:971.

25 Roth AM, Foos RY: Surface structure of the optic nerve head. 1. Epipapillary membranes. Am J Ophthalmol 1972;74:977-985.

26 Rentsch FJ: The ultrastructure of preretinal macular fibrosis. Graefes Arch Clin Exp Ophthalmol 1977;203:321-337.

-27 Kampik A, Kenyon KR, Michels RG, Green WR, de la Cruz ZC: Epiretinal and vitreous membranes. Comparative study of 56 cases. Arch Ophthalmol 1981;99:1445-1454.

28 Gandorfer A, Schumann R, Scheler R, Haritoglou C, Kampik A: Pores of the inner limiting membrane in flat-mounted surgical specimens. Retina 2011;31:977-981.

29 Streeten BA: Disorders of the vitreous; in Garner A, Klintworth GK (eds): Pathophysiology of Ocular Disease - A Dynamic Approach, Part B. New York, Dekker, 1982, pp 13811419.

30 Halfter W, Dong S, Dong A, Eller AW, Nischt R: Origin and turnover of ECM proteins from the inner limiting membrane and vitreous body. Eye 2008;22:1207-1213.

31 Candiello J, Balasubramani M, Schreiber EM, Cole GJ, Mayer U, Halfter W, Lin H: Biomechanical properties of native basement membranes. FEBS J 2007;274:2897-2908.

32 Henrich PB, Monnier CA, Halfter W, Haritoglou C, Strauss RW, Lim RY, Loparic M: Nanoscale topographic and biomechanical studies of the human internal limiting membrane. Invest Ophthalmol Vis Sci 2012;53: 2561-2570.

33 Wollensak G, Spoerl E, Wirbelauer C, Pham DT: Influence of indocyanine green staining on the biomechanical strength of porcine internal limiting membrane. Ophthalmologica 2004;218:278-282.

34 Wollensak G: Biomechanical changes of the internal limiting membrane after indocyanine green staining. Dev Ophthalmol 2008; 42:82-90.

35 Foote CS: Definition of type I and type II photosensitized oxidation. Photochem Photobiol 1991;54:659.

36 Haritoglou C, Gandorfer A, Gass CA, Schaumberger M, Ulbig MW, Kampik A: The effect of indocyanine-green on functional outcome of macular pucker surgery. Am J Ophthalmol 2003;135:328-337.

37 Enaida H, Sakamoto T, Hisatomi T, Goto Y, Ishibashi T: Morphological and functional damage of the retina caused by intravitreous indocyanine green rat eyes. Graefes Arch Clin Exp Ophthalmol 2002;240:209-213.

38 Gandorfer A, Haritoglou C, Gandorfer A, Kampik A: Retinal damage from indocyanine green in experimental macular surgery. Invest Ophthalmol Vis Sci 2003;44:316-323.
39 Sippy BD, Engelbrecht NE, Hubbard GB, Moriarty SE, Jiang S, Aaberg TM Jr, Aaberg TM Sr, Grossniklaus HE, Sternberg P: Indocyanine green effect on cultured human retinal pigment epithelial cells: implication for macular hole surgery. Am J Ophthalmol 2001;132: 433-435.

-40 Stalmans P, Van Aken EH, Veckeneer M, Feron EJ, Stalmans I: Toxic effect of indocyanine green on retinal pigment epithelium related to osmotic effects of the solvent. Am J Ophthalmol 2002;134:282-285.

41 Peters S, Altvater A, Bopp S, Vonthein R, Szurman P, Spitzer MS, Warga M, Lueke M, Bartz-Schmidt KU, Grisanti S: Systemic evaluation of ICG and trypan blue related effects on ARPE-19 cells in vitro. Exp Eye Res 2007; 85:880-889.

42 Rodrigues EB, Penha FM, Farah ME, de Paula Fiod Costa E, Maia M, Dib E, Bottós J, Freymuller E, Furlani B, Meyer CH, Magalhães O Jr, Lima-Filho AA, Safatle A: Preclinical investigation of the retinal biocompatibility of six novel vital dyes for chromovitrectomy. Retina 2009;29:497-510.

43 Mackenzie SE, Gandorfer A, Rohleder M, Schumann R, Schlottmann PG, Bunce C, Xing W, Gregor Z, Charteris DG: Ultrastructure and retinal imaging of internal limiting membrane: a clinicopathologic correlation of trypan blue stain in macular hole surgery. Retina 2010;30:655-661.

44 Mackenzie SE, Gandorfer A, Rohleder M, Schumann R, Schlottmann PG, Bunce C, Xing W, Gregor Z, Charteris DG: Ultrastructure and retinal imaging of epiretinal membrane: a clinicopathologic correlation of trypan blue staining in epiretinal membrane surgery. Retina 2010;30:648-654.

-45 Enaida H, Hisatomi T, Hata Y, Ueno A, Goto Y, Yamada T, Kubota T, Ishibashi T: Brilliant blue $\mathrm{G}$ selectively stains the internal limiting membrane/brilliant blue G-assisted membrane peeling. Retina 2006;26:631-636.

46 Ueno A, Hisatomi T, Enaida H: Biocompatibility of brilliant blue $\mathrm{G}$ in a rat model of subretinal injection. Retina 2007;27:499-504.

47 Januschowski K, Mueller S, Spitzer MS, Schramm C, Doycheva D, Bartz-Schmidt KU, Szurman P: Evaluating retinal toxicity of a new heavy intraocular dye, using a model of perfused and isolated retinal cultures of bovine and human origin. Graefes Arch Clin Exp Ophthalmol 2012;250:1013-1022.

48 Rodrigues EB, Meyer CH, Mennel S, Farah ME: Mechanisms of intravitreal toxicity of indocyanine green dye: implications for chromovitrectomy. Retina 2007;27:958-970.

49 Schumann RG, Remy M, Grueterich M, Gandorfer A, Haritoglou C: How it appears: electron microscopic evaluation of internal limiting membrane specimens obtained during brilliant blue $\mathrm{G}$ assisted macular hole surgery. Br J Ophthalmol 2008;92:330-331. 
50 Farah ME, Maia M, Rodrigues EB: Dyes in ocular surgery: principles for use in chromovitrectomy. Am J Ophthalmol 2009;148:332340.

-51 Gass CA, Haritoglou C, Schaumberger M, Kampik A: Functional outcome of macular hole surgery with and without indocyaninegreen assisted internal limiting membrane peeling. Graefes Arch Clin Exp Ophthalmol 2003;241:716-720.

- 52 Sivalingam A, Eagle RC Jr, Duker JS, Brown GC, Benson WE, Annesley WH Jr, Federman $\mathrm{J}$ : Visual prognosis correlated with the presence of internal-limiting membrane in histopathologic specimens obtained from epiretinal membrane surgery. Ophthalmology 1990; 97:1549-1552.

53 Terasaki H, Mijake Y, Nomura R, Piao CH, Hori K, Niwa T, Kondo M: Focal macular ERGs in eyes after removal of macular ILM during macular hole surgery. Invest Ophthalmol Vis Sci 2001;42:229-234.
54 Tadayoni R, Paques M, Massin P, Mouki-Benani S, Mikol J, Gaudric A: Dissociated optic nerve fiber layer appearance of the fundus after idiopathic epiretinal membrane removal. Ophthalmology 2001;108:2279-2283.

55 Ito Y, Terasaki H, Takahashi A, Yamakoshi T, Kondo M, Nakamura M: Dissociated optic nerve fiber layer appearance after internal limiting membrane peeling for idiopathic macular holes. Ophthalmology 2005;112: 1415-1420.

56 Mitamura Y, Ohtsuka K: Relationship of dissociated optic nerve fiber layer appearance to internal limiting membrane peeling. Ophthalmology 2005;112:1766-1770.

57 Haritoglou C, Ehrt O, Gass CA, Kristin N, Kampik A: Paracentral scotomata: a new finding after vitrectomy for idiopathic macular hole. Br J Ophthalmol 2001;85:231-233.

58 Kim CY, Lee JH, Lee SJ, Koh HJ, Lee SC, Kwon OW: Visual field defect caused by nerve fiber layer damage associated with an internal limiting lamina defect after uneventful epiretinal membrane surgery. Am J Ophthalmol 2002;133:569-571.
59 Lim JW, Kim HK, Cho DY: Macular function and ultrastructure of the internal limiting membrane removed during surgery for idiopathic epiretinal membrane. Clin Exp Ophthalmol 2011;39:9-14.

60 Tari SR, Vidne-Hay O, Greenstein VC, Barile GR, Hood DC, Chang S: Functional and structural measurements for the assessment of internal limiting membrane peeling in idiopathic macular pucker. Retina 2003;27: 567-572.

61 Christensen UC, Kroyer K, Sander B, Larsen M, Henning V, Villumsen J, la Cour M: Value of internal limiting membrane peeling in surgery for macular hole stage 2 and 3: a randomized clinical trial. Br J Ophthalmol 2009;93: 1005-1015.

62 Alkabes M, Salinas C, Vitale L, Burés-Jelstrup A, Nucci P, Mateo C: En face optical coherence tomography of inner retinal defects after internal limiting membrane peeling for idiopathic macular hole. Invest Ophthalmol Vis Sci 2011;52:8349-8355. 